Univerzitet u Beogradu
Poljoprivredni fakultet
Institut za poljoprivrednu tehniku
Naučni časopis
POLJOPRIVREDNA TEHNIKA
Godina XLVI
Broj 3., 2021.
Strane: $49-60$

\title{
DISTANCE-BASED VEGETATION INDICES COMPUTED BY SAGA GIS: A COMPARISON OF THE PERPENDICULAR AND TRANSFORMED SOIL ADJUSTED APPROACHES FOR THE LANDSAT TM IMAGE
}

\author{
Polina Lemenkova*1 \\ ${ }^{I}$ Schmidt Institute of Physics of the Earth, Russian Academy of Sciences \\ Bolshaya Gruzinskaya St, 10, Bld. 1, Moscow 123995, Russia
}

\begin{abstract}
Landsat-TM of 2001 covering Iceland $\left(15.5^{\circ} \mathrm{W}-21^{\circ} \mathrm{W}, 64.5^{\circ} \mathrm{N}-67^{\circ} \mathrm{N}\right)$ was processed using SAGA GIS for testing distance-based Vegetation Indices (VIs): four approaches of Perpendicular Vegetation Index (PVI) and two approaches of Transformed Soil Adjusted Vegetation Index TSAVI. The PVI of vegetation from the soil background line indicated healthiness as a leaf area index (LAI). The results showed that the reflectance for vegetation has a linear relation with soil background line. Four PVI models and two TSAVI shown coefficients of determination with LAI. The dataset demonstrate variations in the calculated coefficients. The mode in the histograms of the PVI based on four different algorithms show the difference: -7.1, -8.36, 2.78 and 7.0 The dataset for the two approaches of TSAVI: first case ranges in 4.4.-80.6 with a bellshape mode of a histogram (8.09 to 23.29) for the first algorithm and an irregular shape for the second algorithm with several modes starting from 0.11 to 0.2 and decreasing to 0.26. SAGA GIS permits the calculation of PVI and TSAVI by computed NDVI based on the intersection of vegetation and soil background. Masking the NIR and R, a linear regression of grids was performed using an equation embedded in SAGA GIS. The advantages of the distance-based PVI and TSAVI consists in the adjusted position of pixels on the soil brightness line which refines it comparing to the slope-based VIs. The paper demonstrates SAGA GIS application in agricultural studies.
\end{abstract}

Key words: SAGA GIS, landsat TM, cartography, Vegetation Index, PVI, TSAVI, agriculture, mapping, iceland, environment

\footnotetext{
*Corresponding Author: pauline.lemenkova@gmail.com
} 


\section{INTRODUCTION}

Recently, vegetation indices computed using various GIS software based on the Landsat TM images have been often used in agricultural sciences to monitor vegetation and crop from space [43, 31].

The fundamental theoretical properties of this approach consists of a combinations of visible and near-infrared (NIR) spectral reflectance of various land cove types [1]. Because bare soils, vegetation, rocks, sand, urban spaces (eg. asphalt roads) and vegetation of various greenness have different spectral reflectance values [14, 22, 29], it can be used to detect the contours of these land cover types in general, and vegetation in particular using specially developed vegetation indices (VIs). As a result, various bands of the electromagnetic spectrum (red, green, blue, NIR) are being applied to monitor crop cover, health and yield, nitrogen stress, and soil moisture in agricultural mapping.

Quantitative indices of vegetation conditions are based on the principal contrast between the absorption and scattering of the $\mathrm{R}$ and NIR. Combined in mathematical equations, the VIs can give the numerical expression of the vegetation health. The most well-known VI is probably a normalized difference vegetation index (NDVI) often used in literature [17, 48, 49, 34, 35, 19]. The VIs correlate with the leaf greenness and canopy density. In this way, it indicates at the vegetation health [7].

The VIs are sensitive to the external factors: solar illumination, angle geometry, effects from the soil background and atmosphere (cloudiness, particles). The responses to the external factors are complex, reflecting surface background properties [47]. The NDVI is one of the slope-based VIs, in contrast with the distance-based VIs. The distance-based VIs (Perpendicular and Transformed Soil Adjusted VIs: PVI and TSAVI) corrected for the soil background effects are the aim of this study.

The study area is located in northern Iceland near the Eyjafjörður and the Skagafjörður fjords, the prosperous agricultural regions. The landscapes in northern Iceland are strongly affected by severe climate settings, glacier and ice coverage, and anthropogenic effects (cattle grazing). The geologic setting include Tjörnes Fracture Zone east of Eyjafjörður fjord which separates the northern volcanic zone of Iceland from the Kolbeinsey Ridge and has a sedimentary basin with $4 \mathrm{~km}$ of sediment thickness, [12].

The Tjörnes Fracture Zone presents an 80-km-wide zone of high seismicity, an oblique transform fault, along which shifted the rift zone in North Iceland joining the mid-ocean Kolbeinsey Ridge [20]. The western part of this basin has a graben with numerous listric normal faults which is a continuation of the spreading axis on the Kolbeinsey Ridge [21]. Complex geologic setting create conditions of volcanism which in turn cause the formation of the erosion -prone soils. As a result, one of the modern problems in today's environment of Iceland is the land degradation and soil erosion, [16, 25]. At the same time, land cover and vegetation types distributed in Iceland present an important Nordic environment and habitat for fauna explaining the actuality of the study. 


\section{Data}

\section{MATERIALS AND METHODS}

The data include the Landsat TM satellite image processed for the detection of vegetation and environmental monitoring in a northern region of Iceland by applying Perpendicular Vegetation Index (PVI).

The remote sensing data were processed in a SAGA GIS (System for Automated Geoscientific Analyses) software [6]. The Landsat TM data was captured in 08 August 2001 with the coordinates extent roughly $15.5^{\circ} \mathrm{W}-21^{\circ} \mathrm{W}, 64.5^{\circ} \mathrm{N}-67^{\circ} \mathrm{N}$ (precise specification is given in Table 1). The WESN coordinates of the dataset are as follows: West: $19^{\circ} 43^{\prime} 06.88^{\prime \prime} \mathrm{W}$, East: $17^{\circ} 24^{\prime} 06.69^{\prime \prime} \mathrm{W}$, North: $66^{\circ} 38^{\prime} 00.38^{\prime \prime N}$, South: 64³1'53.82"N. Resampling Technique: CC (Cubic Convolution), Product Type: Systematic Terrain (L1Gt), Datum: WGS84, Zone 27, Time Series: GLS2000, Orientation: NUP (North Up), Entity ID: P219R014_7X20010908, WRS Path 2019, WRS Row 14.

\section{Algorithms}

This study uses the PVI calculated for the study area. Although the NDVI is still a leading VI in remote sensing applications, the reason for using distance-based VIs is explained by the more sparse vegetation with requires adjusted equation to improve on the NDVI in the assessment of vegetation parameters. Thus, the main objective of the distance-based VIs is to remove the influence of soil brightness where vegetation is sparse and pixels contain a mixture of green vegetation and soil background.

The algorithm of the distance-based VIs consists in soil line calculation developed to minimize its influences. These indices are more reliable and less noisy than NDVI for sparse vegetation, although they are not widely used comparing to the NDVI. However, since vegetation in Iceland is in many areas sparse, these types of VIs can be suitable for the vegetation monitoring. The soil line represents a signature of soils in an R/NIR. The explanation of the correlation between VIs and spectral reflectance of vegetation is still subject to much discussion $[24,32,33,11]$.

Applications of the VIs can include Leaf Area Index (LAI) estimation by regressing the vegetation index against the measurements of plant parameter. Two variants of the VIs were calculated in this work, with the difference between them in the regression performed using the R or NIR bands as an independent variable. Hence, these VIs were tested in two groups: 1) PVI using $\mathrm{R}$ as independent variable [55, 47]; 2) PVI with NIR as as independent variable using existing approaches $[50,46]$.

\section{SAGA GIS Methodology}

The PVI calculation has been applied using the SAGA GIS module classified using path Geoprocessing $>$ Imagery $>$ Vegetation Indices $>$ Vegetation Index (Distance Based). There are four perpendicular Vis, [50, 46, 55, 47] and two methods of the Transformed Soil Adjusted Vis, $[3,4]$. These approaches have been tested and presented in this work for a comparative analysis in the algorithm of SAGA GIS and the output visualization.

In this work, the two VIs were used to estimate vegetation cover and the vigor of vegetation (greenness). The distance-based VIs that were calculated with SAGA GIS by two input raster layers of the Landsat TM image: 
one with NIR band values and the second of $\mathrm{R}$ band values. Comparing to the slopebased VIs, the algorithm of the distance-based VIs is more complicated and require previous preparation of the image. Four perpendicular VIs have been computed in this study: 1) PVI [50]; 2) PVI [46]; 3) PVI [55]; 4) PVI [47].

Before the calculation of the distance-based VIs, the slope of the soil line and the interception of the soil line fields were calculated. The values were entered as the parameters in the SAGA GIS menu. This was achieved by the calculation of the NDVI as a slope-based VI. Using the computed NDVI, the areas that represent bare soil were selected. Afterwards, the raster grid containing 'one' in bare soil cells and 'no data' value in all the rest ones were created. The mask grid was applied to R and NIR raster grids.

A simple linear regression using the grids was performed thereafter using an equation ' $y=a x+b$ ', where ' $a$ ' is the slope of the soil line and b is the intercept. Thus, this linear regression of the NIR band against the $\mathrm{R}$ band is suitable for a sample of the bare soil pixels. Pixels near the soil line are interpreted as 'soil' class, while those with a distance far away are classified as 'vegetation'.

\section{RESULTS AND DISCUSSION}

The spectral vegetation indices (VIs) use the well-known characteristic shape of the green vegetation spectrum by combining the low reflectance in the visible part of the spectrum with the high reflectance in the near infrared.

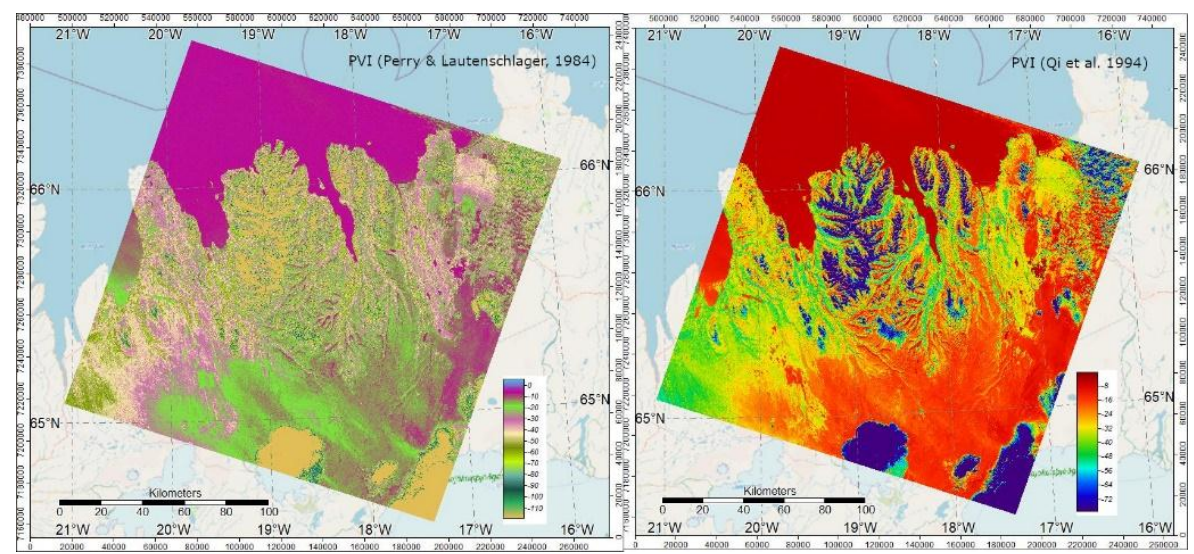

Figure 1. Left: PVI. Right: PVI. Mapping: SAGA GIS. Source: author. 

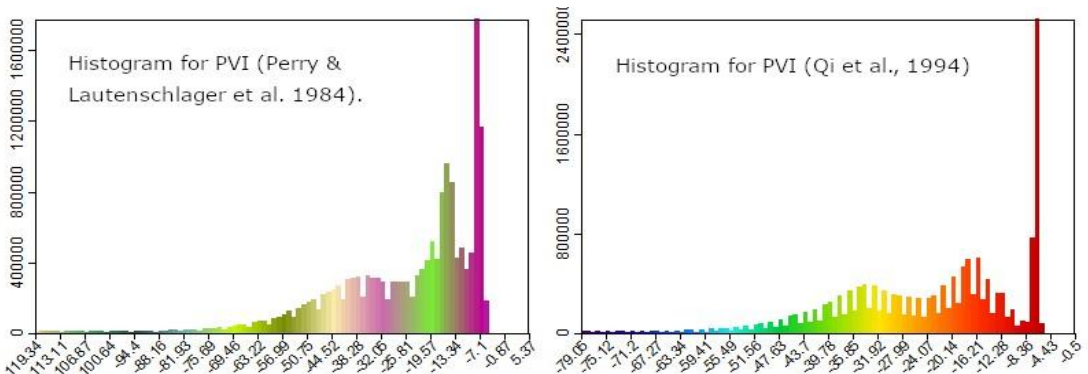

Figure 2. Histograms of pixels' frequency. Left: PVI (Perry \& Lautenschlager et al., 1984) Right: PVI (Qi et al., 1994). Plotting: SAGA GIS. Source: author.

The combination may be in the form of a ratio, a slope, or some other formulation. Indices may be broadly separated into three categories:

1) intrinsic indices (such as the simple ratio and the NDVI), which do not involve any external factor other than the measured spectral reflectances;

2) soil-line related indices, which include soil-line parameters, such as the perpendicular VI (PVI), the weighted difference vegetation index, the soil-adjusted VI or SAVI [23], the transformed SAVI TSAVI [3].

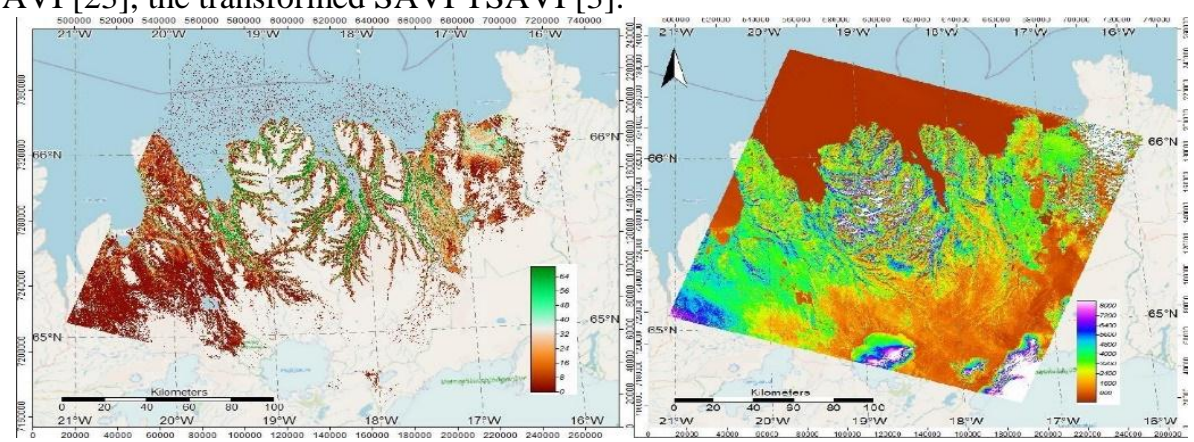

Figure 3. Left: PVI (Richardson \& Wiegand, 1977), right: PVI (Walther \& Shabaani, 1991).

Mapping: SAGA GIS. Source: author.

The results of the applied methodology in the presented research is useful to the environmental scientists and agricultural crop studies applying SAGA GIS for analysis of sustainable development, land degradation and resource conservation.
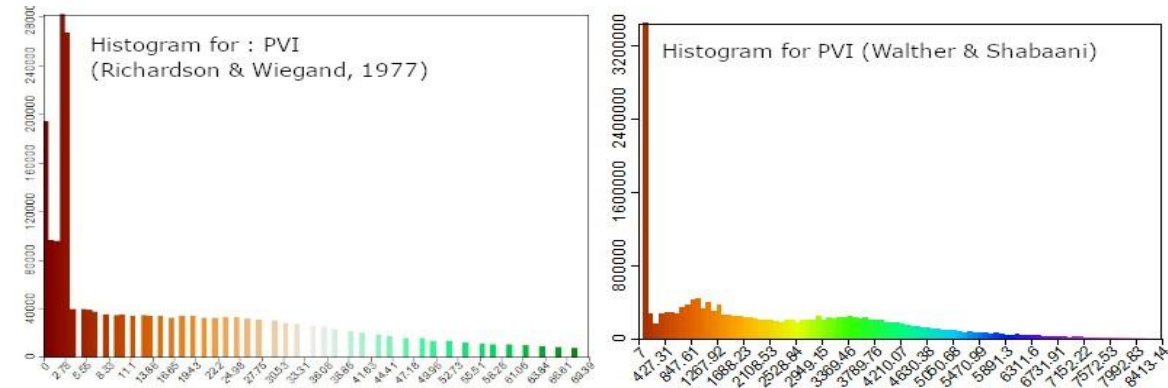

Figure 4. Histograms of pixels' frequency. Left: PVI (Richardson \& Wiegand, 1977), right: PVI (Walther \& Shabaani, 1991). Plotting: SAGA GIS. Source: author. 
The results of this study present a comparative analysis of the VIs: PVI based on [46, 47] (Figure 1) and histogram (Figure 2). Showing the difference between these two approaches, it can be seen that the mode of the data set has a values of -7.1 for the case of [46] and -8.36 for the approach of [47]. Two minor peaks are notable for the ranges 56.99 to 25.81 and $19.57-13.34$ for the first case and 43.7 to 27.99 with 20.14 to 16.21 for the second one.

In the output image in Figure 3 and Figure 4, the dataset and its histogram present approaches of PVI modelling by methods of [50] and [55] respectively. The histograms of both cases demonstrates similar behavior with a single mode in the lowest values. However, the absolute values differ according to the algorithm: the mode for the first case is $0-2.78$ and the dataset extends to 69.39 , while the second case has a peak in 7 to 427.31 and the dataset extends up to 8413.14 , showing that the case of [50] is better calibrated.

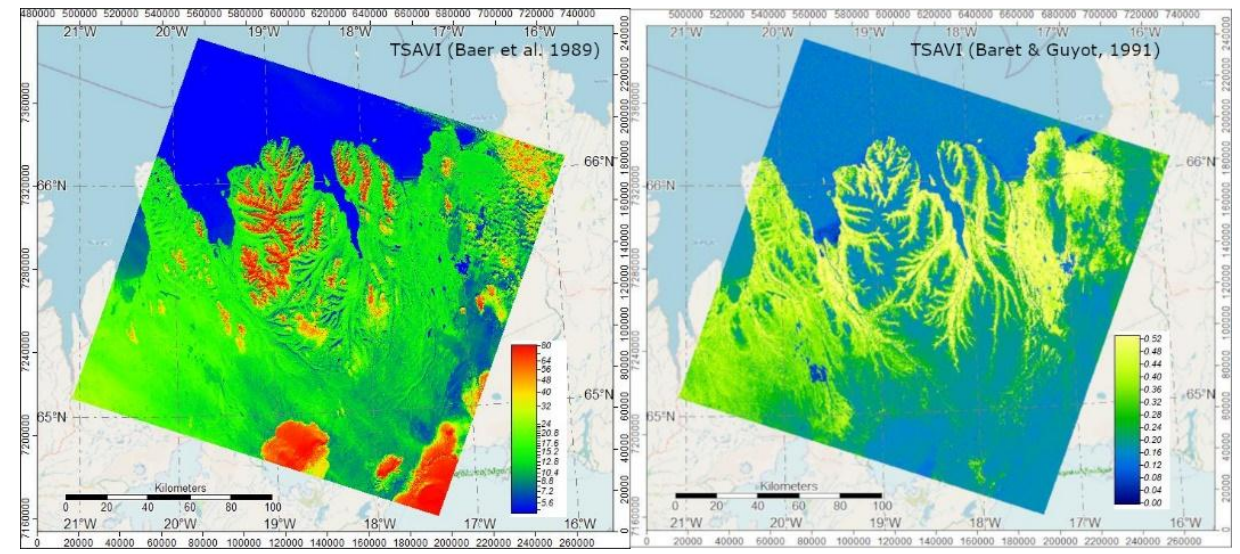

Figure 5. Left: TSAVI (Baert et al., 1989). Right: TSAVI (Baert \& Guypt, 1991). Mapping: SAGA GIS. Source: author.

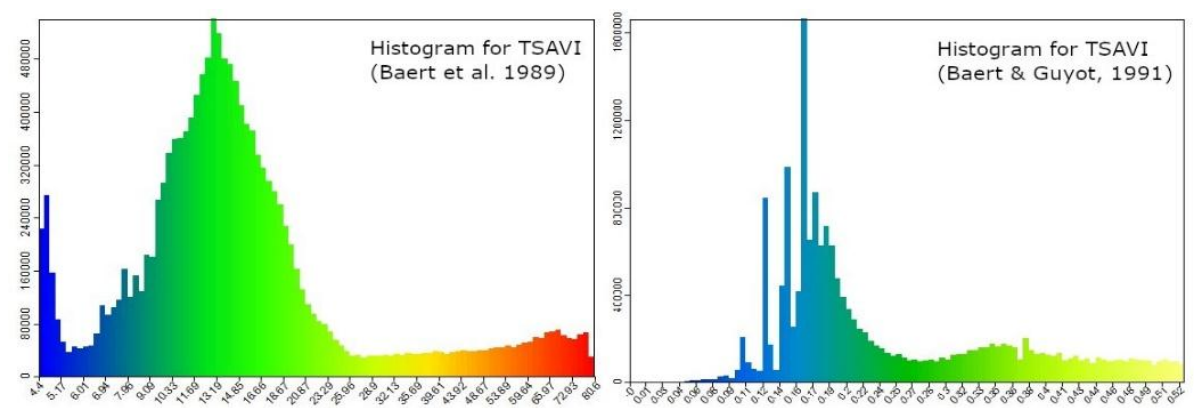

Figure 6. Histograms left: TSAVI (Baert et al., 1989), right: TSAVI (Baert \& Guypt, 1991). Plotting: SAGA GIS. Source: author.

The dataset in Figure 5 and Figure 6 show the two approaches of the TSAVI computing. The dataset for the first case ranges from 4.4 to 80.6 with a bell-shape mode between 8.09 to 23.29 for the first case and an irregular shape. 
The dataset of the last one is calibrated from 0 to 1 (more precisely, 0.0 to 0.62 ) with several modes starting from 0.11 to 0.2 and then progressively decreasing to 0.26 .

A second slight increase in values can be seen in the interval of 0.33 to 0.38 . The cartographic output image in Figure 7 shows the RGB color band composite (band 61band 62-band 5).

However, the gain is set differently: band 61 is set to 'low' gain mode for the case of high surface brightness (e.g., desert, or less vegetated areas as in mountainous areas of Iceland). The band 62 is set to 'high' gain mode to maximize the instrument's 8-bit radiometric resolution without saturating the detectors. Both bands have identical detectors using the same wave width and band width.

The combination of the bands 61,62 and 5 gives the effects of very bright icecovered areas. The image on the right in Figure 7 shows the simulation of the Universal Image Quality Index and designed by modeling image distortion as a combination of factors: loss of correlation, luminance, contrast distortion. This research demonstrated testing and comparing the sensitivity of the distance-based VIs to remove soil background effects and better discriminate vegetation from the other land cover types, such as bare soils. The spectral reflectance of a vegetation, is a combination of the reflectance of plant leafs with soil, controlled by the optical properties of these elements. Logically, along with the growth of the vegetation, the soil contribution gradually decreases. However, it still remain a significant noise, depending on leaf density, canopy geometry, atmospheric effects (sun, wind). In this context, limitation of the soil reflectance and highlighting vegetation instead of soil background its the aim of the distance-based VIs, such as PVI and TSAVI simulating a typical healthy green canopy.

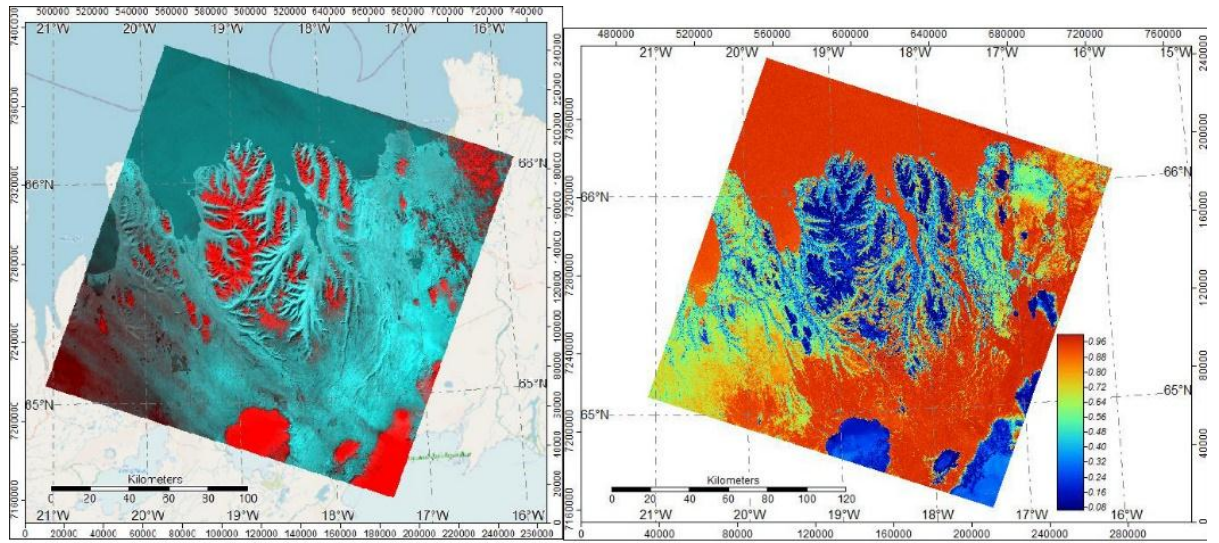

Figure 7. Left: RGB color band composite (band 61-band 62-band 5).

Right: Universal Image Quality Index. Mapping: SAGA GIS. Source: author.

\section{CONCLUSION}

This paper demonstrated the use of the computed and visualized PVI that takes into account the soil emissivity (one of the major drawbacks of NDVI) applied for the landscapes of Iceland. 
However, extracting vegetation from the Landsat TM satellite image is often affected by the external atmospheric effects: clouds, pollutants, submicron particulate matter, which requires atmospheric correction and limits the application of the remote sensing.

The Landsat TM satellite imagery dataset can be used to compute the vegetation areas at a finer scale using the distance-based vegetation induces rather than traditionally used NDVI $[2,5,8]$.

The results of the present work suggested that PVI can be used for accurate detection of vegetation in hardly accessible region of Iceland. As such, it allows more accurate environmental monitoring and agricultural management of Iceland, especially in the vulnerable areas with eroded soils [18] and as in certain regions of Iceland affected by climate change and glacier retreat $[9,10]$. The presented models of PVI are based on varying algorithms developed concurrently by different author. In general, the behavior of the PVI is similar to Tasseled Cap greenness and the 2nd Principal Component in its approach. The PVI demonstrates to be less sensitive to the soil emissivity than other vegetation indices, like NDVI [13, 15] or SAVI [23].

Application of various machine learning methods in geosciences using algorithms of automatization allow precise cartographic mapping that significantly updates the traditional cartographic routine, through the application of scripting languages, [37, 38, $39,51]$, which is noticeable in comparison to previous studies with traditional GIS applications, [53, 54, 44, 26, 27, 30, 45]. Supported by scripting approaches such studies rely on the processing of high-resolution datasets [36, 42]. Using machine learning methods in geosciences increases the speed of the data processing and the precision of the resulting graphs and maps.

However, in many cases, such as vegetation mapping, topographic or geologic variables are not enough to highlight the spatial characteristics of the environment. Taking into account satellite imagery brings cartography towards advanced modelling of the geographic phenomena: the regression models of the VIs are characterized by complex combination of several variables of spectral bands indicating vegetation contours. The exact combination of NIR/R and other variables varies, including previously calculated NDVI. The distance-based VIs differ in logic and technical workflow from the slope-based VIs. The advantage of the RS method of SAGA GIS for vegetation is the quality of image processing.

The SAGA GIS based mapping allows detailed determination of vegetation from other land cover types, enabling unequivocal separation of green areas from bare soils, water and urban spaces, as well as to assess the healthiness of leaf canopy. This is particularly important in zones where the vegetation areas are directly adjacent to other land cover types, or in unreachable areas where direct observations and fieldwork are difficult to undertake. Statistical data visualization and using computations and advanced methods of data processing are widely used in geosciences [28, 40, 41, 52]. The approaches of the remote sensing present a step forward in image processing for vegetation and agricultural mapping.

\section{REFERENCES}

[1] Abburu, S., Golla, S.B. 2015. Satellite Image Classification Methods and Techniques: A Review. International Journal of Computer Applications, 119(8): pp. 20-25. 
[2] Ahmet, K.R., Akter, S. 2017. Analysis of landcover change in southwest Bengal delta due to floods by NDVI, NDWI and K-means cluster with Landsat multi-spectral surface reflectance satellite data. Remote Sensing Applications: Society and Environment, 8: pp.168-181.

[3] Baret, F., Guyot, G. 1991. Potential and limitations of vegetation indices for LAI and APAR assessment. Remote Sensing of Environment, 104: pp.88-95.

[4] Baret, F., Guyot, G., Major, D. 1989. TSAVI: A vegetation index which minimizes soil brightness effects on LAI and APAR estimation. Conference IEEE Xplore.

[5] Bhandari, A.K., Kumar, A., Singh, G.K. 2012. Feature Extraction using Normalized Difference Vegetation Index (NDVI). a Case Study of Jabalpur City. Procedia Technology, 6: pp.612-621.

[6] Böhner J., Blaschke T., Montanarella L. 2008. SAGA - Seconds Out. Hamburger Beiträge zur Physischen Geographie und Landschaftsökologie, 19, 113 pp.

[7] Broge, N.H., Leblanc, E. 2001. Comparing prediction power and stability of broadband and hyperspectral vegetation indices for estimation of green leaf area index and canopy chlorophyll density. Remote Sensing of Environment, 76: pp.156-172.

[8] du Plessis, W.P. 1999. Linear regression relationships between NDVI, vegetation and rainfall in Etosha National Park, Namibia. J. Arid Environ, 42: pp.235-260.

[9] Erlendsson, E. 2007. Environmental Change Around the Time of the Norse Settlement of Iceland. University of Aberdeen, Aberdeen, pp.301.

[10] Etzelmüller, B., Patton, H., Schomacker, A., Czekirda, J., Girod, L., Hubbard, A., Lilleøren, K.S., Westermann, S. 2020. Icelandic permafrost dynamics since the Last Glacial Maximum - model results and geomorphological implications. Quaternary Science Review, 233: 106236.

[11] Evangelides, C., Nobajas, A. 2020. Red-Edge Normalised Difference Vegetation Index (NDVI705) from Sentinel-2 imagery to assess post-fire regeneration. Remote Sensing Applications: Society and Environment, 17: 100283.

[12] Flovenz, O.G., Gunnarsson, K. 1991. Seismic crustal structure in Iceland and surrounding area. Tectonophysics, 189: pp.1-17.

[13] French, A.N., Hunsaker, D.J., Sanchez, C.A., Saber, M., Gonzalez, J.R., Anderson, R. 2020. Satellite-based NDVI crop coefficients and evapotranspiration with eddy covariance validation for multiple durum wheat fields in the US Southwest. Agricultural Water Management, 239: 106266.

[14] Gao, L., Wang, X., Johnson, B.A., Tian, Q., Wang, Y., Verrelst, J., Mu, X., Gu, X. 2020. Remote sensing algorithms for estimation of fractional vegetation cover using pure vegetation index values: A review. ISPRS Journal of Photogrammetry and Remote Sensing, 159: pp.364-377.

[15] Gim, H.-J., Ho, C.-H., Jeong, S., Kim J., Feng, S., Hayes, M.J. 2020. Improved mapping and change detection of the start of the crop growing season in the US Corn Belt from long-term AVHRR NDVI. Agric For Meteorol, 294: pp.108143.

[16] Gísladottir, G. 2001. Ecological Disturbance and Soil Erosion on Grazing Land in Southwest Iceland. Land Degradation. Springer, 109-126.

[17] Gonçalves, R.M., Saleem, A., Queiroz, H.A.A., Awange, J.L. 2019. A fuzzy model integrating shoreline changes, NDVI and settlement influences for coastal zone human impact classification. Applied Geography, 113: 102093.

[18] Greipsson, S. 2012. Catastrophic soil erosion in Iceland: impact of long-term climate change, compounded natural disturbances and human driven land use changes. Catena, 98: pp.41-54. 
[19] Gu, Y., Wylie, B.K., Howard, D.M., Phuyal, K.P., Jia, L. 2013. NDVI saturation adjustment: A new approach for improving cropland performance estimates in the Greater Platte River Basin, USA. Ecological Indicators, 30, pp.1-6.

[20] Gudmundsson, A., Brynjolfsson, S., Jonsson, M.T. 1993. Structural analysis of a transform fault-rift zone junction in north Iceland. Tectonophysics, 220: pp.205-221.

[21] Hannington, M., Herzig, P., Stoffers, P., Scholten, J., Botz, R., Garbe-Schönberg, D., Jonasson, I.R., Roest, W., Shipboard Scientific Party 2001. First observations of hightemperature submarine hydrothermal vents and massive anhydrite deposits off the north coast of Iceland. Marine Geology, 177(3-4): pp.199-220.

[22] He, L., Zhang, H., Zhang, Y., Song, X., Feng, W., Kang, G., Wang, C., Guo, T. 2016. Estimating canopy leaf nitrogen concentration in winter wheat based on multi-angular hyperspectral remote sensing. European Journal of Agronomy, 73: pp.170-185.

[23] Huete, A.R. 1988. A soil-adjusted vegetation index (SAVI). Remote Sens. Environ., 25(3): pp.295-309.

[24] Ireland, G., Petropoulos, G.P. 2015. Exploring the relationships between post-fire vegetation regeneration dynamics, topography and burn severity: A case study from the Montane Cordillera Ecozones of Western Canada. Appl Geogr, 56: 232-248.

[25] Kardjilov, M., Gisladottir, G., Gislason, S. 2006. Land degradation in northeastern Iceland: present and past carbon fluxes. Land Degrad Dev, 17(4): pp.401-417.

[26] Klaučo, M., Gregorová, B., Stankov, U., Marković, V., Lemenkova, P. 2013a. Determination of ecological significance based on geostatistical assessment: a case study from the Slovak Natura 2000 protected area. Open Geosci., 5(1): 28-42.

[27] Klaučo, M., Gregorová, B., Stankov, U., Marković, V., Lemenkova, P. 2013b. Interpretation of Landscape Values, Typology and Quality Using Methods of Spatial Metrics for Ecological Planning. Environmental and Climate Technologies, October 14, 2013. Riga, Latvia.

[28] Klaučo, M., Gregorová, B., Stankov, U., Marković, V., Lemenkova, P. 2014. Landscape metrics as indicator for ecological significance: assessment of Sitno Natura 2000 sites, Slovakia, Ecology and Environmental Protection. Proceedings of the International Conference, 19-20, 2014. Minsk, Belarus, pp.85-90.

[29] Lemenkova, P. 2011. Seagrass Mapping and Monitoring Along the Coasts of Crete, Greece. M.Sc. Thesis. University of Twente, Enschede, Netherlands.

[30] Lemenkova, P., Promper, C., Glade, T. 2012. Economic Assessment of Landslide Risk for the Waidhofen a.d. Ybbs Region, Alpine Foreland, Lower Austria. In Protecting Society through Improved Understanding. 11 th International Symposium on Landslides $\&$ the $2^{\text {nd }}$ North American Symposium on Landslides \& Engineered Slopes (NASL), June 2-8, 2012. Banff, Canada,pp. 279-285.

[31] Lemenkova, P. 2013. Monitoring Changes in Agricultural Landscapes of Central Europe, Hungary: Application of ILWIS GIS for Image Processing. Geoinformatics: Theoretical and Applied Aspects, Kiev, 13-16 May, 2013.

[32] Lemenkova, P. 2014a. Detection of Vegetation Coverage in Urban Agglomeration of Brussels by NDVI Indicator Using eCognition Software and Remote Sensing Measurements. In: GIS and Remote Sensing, November 17-19, 2014, Tsaghkadzor, Armenia, pp.112-119.

[33] Lemenkova, P. 2014b. Opportunities for Classes of Geography in the High School: the Use of 'CORINE' Project Data, Satellite Images and IDRISI GIS for Geovisualization. In: Persp. for the Development of Higher Education. Belarus, Grodno, pp. 284-286.

[34] Lemenkova, P. 2020. Hyperspectral Vegetation Indices Calculated by Qgis Using Landsat TM Image: a Case Study of Northern Iceland. Advanced Research in Life Sciences, 4(1): pp.70-78. 
[35] Lemenkova, P. 2020. Sentinel-2 for High Resolution Mapping of Slope-Based Vegetation Indices Using Machine Learning by SAGA GIS. Transylvanian Review of Systematical and Ecological Research, 22(3): pp.17-34.

[36] Lemenkova, P. 2018. R scripting libraries for comparative analysis of the correlation methods to identify factors affecting Mariana Trench formation. Journal of Marine Technology and Environment, 2: pp. 35-42.

[37] Lemenkova, P. 2019. Statistical Analysis of the Mariana Trench Geomorphology Using R Programming Language. Geodesy and Cartography, 45(2): 57-84.

[38] Lemenkova, P. 2019. GMT Based Comparative Analysis and Geomorphological Mapping of the Kermadec and Tonga Trenches, Southwest Pacific Ocean. Geographia Technica, 14(2): pp.39-48.

[39] Lemenkova, P. 2020. Java and Sumatra Segments of the Sunda Trench: Geomorphology and Geophysical Settings Analysed and Visualized by GMT. Glasnik Srpskog Geografskog Drustva, 100(2). pp. 1-23.

[40] Lemenkova, P. 2020. GMT Based Comparative Geomorphological Analysis of the Vityaz and Vanuatu Trenches, Fiji Basin. Geodetski List, 74(1). pp. 19-39.

[41] Lemenkova, P. 2020. Using R packages 'tmap', 'raster' and 'ggmap' for cartographic visualization: An example of dem-based terrain modelling of Italy, Apennine Peninsula. Zbornik radova - Geografski fakultet Univerziteta u Beogradu, 68, pp.99-116.

[42] Lemenkova, P. 2020. R Libraries \{dendextend $\}$ and \{magrittr\} and Clustering Package scipy.cluster of Python For Modelling Diagrams of Dendrogram Trees. Carpathian Journal of Electronic and Computer Engineering, 13(1): pp.5-12.

[43] Möllmann, J., Buchholz, M., Kölle, W., Musshoff, O. 2020. Do remotely-sensed vegetation health indices explain credit risk in agricultural microfinance? World Development, 127: 104771.

[44] Moles A. 1964. Théorie de l'information et message cartographique. Revue française des sciences et des techniques, 32:11-16.

[45] Monkhouse, F.J., Wilkinson, H.R. 1976. Maps and Diagrams, Their Compilation and Construction. Methuen \& Co. Ltd., London, 527 p., $3^{\text {rd }}$ ed.

[46] Perry, C.Jr., Lautenschlager, L.F. 1984. Functional Equivalence of Spectral Vegetation Indices. Remote Sensing of Environment, 14(1-3): pp.169-182.

[47] Qi, J., Chehbouni, A., Huete, A.R., Kerr, Y.H., Sorooshian, S. 1994. A modified soil adjusted vegetation index. Remote Sensing of Environment, 48. pp. 119-126.

[48] Raynolds, M.K., Walker, D.A., Maier, H.A. 2006. NDVI patterns and phytomass distribution in the circumpolar Arctic. Remote Sens. Environ., 102(3-4): 271-281.

[49] Raynolds, M.K., Comiso, J.C., Walker, D.A., Verbyla, D. 2008. Relationship between satellite-derived land surface temperatures, arctic vegetation types, and NDVI. Remote Sensing of Environment, 112(4): pp.1884-1894.

[50] Richardson, A.J., Wiegand, C.L. 1977. Distinguishing Vegetation from Soil Background Information. Photogrammetric Engineering and Remote Sensing, 43(12). pp.1541-1552.

[51] Schenke, H.W., Lemenkova, P. 2008. Zur Frage der Meeresboden-Kartographie: Die Nutzung von AutoTrace Digitizer für die Vektorisierung der Bathymetrischen Daten in der Petschora-See. Hydrographische Nachrichten, 81: pp.16-21.

[52] Slocum, T.A., McMaster, R.B., Kessler, F.C., Howard, H.H. 2005. Thematic Cartography and Geography Visualization. Pearson Prentice Hall, 518 pp.

[53] Suetova, I.A., Ushakova, L.A., Lemenkova, P. 2005a. Geoinformation mapping of the Barents and Pechora Seas. Geography and Natural Resources, 4. pp.138-142. 
[54] Suetova, I.A., Ushakova, L.A., Lemenkova P. 2005b. Geoecological Mapping of the Barents Sea Using GIS. In: International Cartographic Conference.

[55] Walther, D., Shabaani, S. 1991. Large Scale Monitoring of Rangeland Vegetation Using NOAA/11 AVHRR LAC Data. Range Management Handbook of Kenya, 3(4). pp.105.

\title{
DALJINSKI INDEKSI VEGETACIJE IZRAČUNATI PROGRAMOM SAGA GIS: POREĐENJE VERTIKALNOG I PRILAGOĐENOG PRISTUPA PROMENA ZEMLJIŠTA ZA SLIKU LANDSAT TM
}

\section{Polina Lemenkova ${ }^{1}$}

\author{
${ }^{1}$ Schmidtov Institut za fiziku Zemlje, Ruska Akademija nauka. Moskva, Rusija
}

Sažetak: Landsat-TM slika je obrađena upotrebom SAGA GIS programa za testiranje indeksa vegetacije na osnovu udaljenosti u poljoprivrednim kartama: 4 pristupa indeksa vertikalne vegetacije (PVI) i 2 indeksa vegetacije TSAVI prilagođenog pristupa.

PVI vegetacije sa linije zemljišta (podloge) ukazivao je na zdravstvenu ispravnost kao indeks lisne površine (LAI). Refleksija vegetacije ima linearni odnos sa linijom pozadine.

Četiri PVI modela i dva TSAVI pokazala su koeficijente determinacije sa LAI. Podaci pokazuju varijacije u izračunatim koeficijentima. Način u histogramima PVI zasnovan na 4 različita algoritma pokazuje razliku: -7,1, -8,36, 2,78 i 7,0.

Skup podataka za 2 pristupa TSAVI: prvi slučaj kreće se u rasponu od 4.4 do 80.6 sa histogramom u obliku zvona (od 8.09 do 23.29) za prvi algoritam i nepravilnim oblikom za drugi algoritam sa nekoliko načina $(0,11$ do 0,2$)$ i opadajućim do 0,26 .

SAGA GIS program prikazuje vrednosti PVI i TSAVI izračunavanjem NDVI na osnovu preseka podataka vegetacije i pozadine podloge (zemljišta).

Upotrebom podataka NIR i R, urađena je linearna regresija pomoću jednačine ugrađene u SAGA GIS. Prednosti PVI i TSAVI sastoje se u prilagođenom položaju piksela na liniji osvetljenja zemljišta što poboljšava u odnosu na VI na temelju nagiba.

U radu je prikazana primjena SAGA GIS programa u poljoprivrednim studijama.

Ključne riječi: SAGA GIS, Landsat TM, kartografija, indeks vegetacije, PVI, TSAVI, poljoprivreda, mapiranje, Island, životna sredina

Prijavljen:

Submitted:

31.04.2021.

Ispravljen:

Revised:

20.05.2021

Prihvaćen:

Accepted:

29.05.2021. 